\title{
Integrating English for Specific Academic Purposes (ESAP) Skills into Mainstream English Courses
}

\author{
Purificación Sánchez Hernández \\ Pascual F. Pérez Paredes \\ University of Murcia \\ purisan@um.es / pascualf@um.es
}

\begin{abstract}
This paper examines the design and implementation stages of a course of English given at the Faculty of Psychology of the University of Murcia, Spain. The course was programmed regardless of the particular individuals and no previous requirements were needed. Two initial tests were passed to the students at the beginning of the semester: the first one to evaluate their needs and motivation and the second one to measure their general communicative competence. The results were heterogeneous. The students were informed of their results and also of the level they should reach to pass the course, especially those with low marks. With respect to their motivation they manifested two orientations: Labour and integrative reasons. Taking into account their 'labour reasons' some units closely related to their speciality were included and the final evaluation was modified giving some weight also to the specific English component ( $75 \%$ GE, $25 \%$ ESAP). The analysis reveals that, according to our initial assumption, those students with a better communicative competence at the beginning of the course obtained the best results in the final exam. A correlation between those students with intrinsic motivation and communicative competence and the best final marks has also been found.
\end{abstract}




\section{Introduction}

English is not only the mother tongue of a part of the world but also the 'language of communication' of the rest of it. It is not new that the term 'communication' involves many levels and different specialities, as many as human activities. In this sense we could speak of the language used by scientists, lawyers, politicians and so on, which, in general, has been named English for Specific Purposes (ESP) by many authors (Kennedy and Bolitho, 1991; Hutchitson and Waters, 1987). It has also been stated (Hutchinson and Water, 1987) that English for Specific Purposes involves different variants such an EST (English for Science and Technology), EOP (English for Occupational Purposes) and EAP (English for Academic Purposes). However, other authors (Widdowson, 1998; Alcaraz, 2000) prefer to use the expression Professional and Academic English(PAE). Notwithstanding, Kennedy and Bolitho (1991) proposed two main divisions, which may help to distinguish between two different ESP situations: English for Occupational Purposes (EOP) and English for Academic Purposes (EAP). Going a little further, Jordan (1997) divides English for Academic Purposes into two branches: English for Specific Academic Purposes (ESAP) and English for General Academic Purposes (EGAP). The origin is the same for all denominations.

In our research we will use Jordan's terminology. The present paper deals with the development of an English course at the Faculty of Psychology of the University of Murcia. The main aim of this work is to report the design and implementation stages of a course of English for students of the $4^{\text {th }}$ and $5^{\text {th }}$ years of the Degree in Psychology.

The course was programmed under the name 'English' as a course of general English for students of intermediate level. However, no previous official academic requirements regarding their competence in the FL were made before its beginning. The course, which spanned a semester, consisted of 50 teaching hours.

When we planned the course we had to deal with several problems. One of the most important was that not all the university Spanish students have studied English at the primary or secondary school and, consequently, they don't have the same average knowledge. This fact results in various learning profiles within the same class. So teachers can have, in the same group, students with a low English level whose interests will mainly be to improve their knowledge of General English (GE), and other students with a higher level for whom an ESAP course would be more interesting. In addition to all these facts, teachers have to consider motivational aspects as well as the number of students per class, which is usually very high in the Spanish University context.

\section{Procedures}

It is well-known that an ESP course should be based on a needs analysis to specify, as closely as possible, what exactly it is that students have to do through the medium of English (Robinson, 1991). There is general agreement that as much as possible the needs analysis 
should be completed before any course or series of courses starts. Richterich and Chancerel (1980) suggest that needs analysis needs to be repeated during the life of each course. In our case a proper needs analysis could not be carried out since it would have not been functional: the syllabus of the course had been programmed in advance independently of the students taking it and before they enrolled the course. However, at the beginning of the course we passed a questionnaire to learn about the students' interests and motivation.

Motivation is a learning determining factor. It involves the learner's reasons for attempting to acquire the second language (Arnold and Douglas, 1999). According to Gardner and Lambert (1972), there are three clues in the learning of a foreign language: the aptitude of the learner, his/her intelligence and his/her motivation. Previously, Gardner and Lambert (1959) had divided motivation into two general orientations: instrumental and integrative. This last one is understood as a positive attitude towards the foreign language speakers, a wish for integration within this group or at least of meeting them. There are other authors reporting about motivation. For example, Aesdibacher (1986) distinguishes between intrinsic and extrinsic motivation. Gardner and Lambert reported that an integrative orientation towards learning a foreign language will result in a better linguistic dominion of the foreign language. Gardner et al. (1979) even stated that an integrative motivation is the basis for the L2 learning although later (Gardner, 1988) he suggested that most of the students with an integrative motivation can get better results in the L2 learning. In summary, integrative motivation has often been considered superior to the instrumental one.

Another problem teachers have to face is to determine students' FL average level. Consequently, at the beginning of the semester our students completed two tests: one in which they were asked about their interests and motivation and a GE test which consisted of two different parts: a lexical test and a use of English (UE) test where we wanted to know about the proficiency level of the students. For the lexical part 40 was the maximum mark; for the UE test 80 . The two marks totalled a maximum score of 120 . We used the Heinemann Test (1998) which is distributed together with the Reward Series. Forty two students took part in the study. Their ages ranged from 21 to $28\left(X=23.05 ; S_{x}=1.59\right)$ and $76.2 \%$ were female students and $23.8 \%$ were male.

With respect to the first questionnaire, the one related to interests and motivation, one of the questions we asked them was why they studied English. We gave them three options: 1) Labour Reasons, 2) I like learning English and 3) English is just another subject in my degree. As it can be seen in Table 1, the class exclusively addressed two of the options: $50 \%$ chose 'Labour reasons' and the other 50\% 'I like learning English'. The third possibility was not selected at all. 'Labour reasons' could be identified as instrumental motivation, that is to say, it has to do with practical reasons for language learning, such as getting promotion, whereas 'I like learning English' is considered to underscore integrative motivation, since the item refers to a desire to learn the language in order to relate to and even become part of the target culture. 
To have a general profile of the class and especially to be sure we did not have beginners in our group, the students were asked about the time they had been studying English and the time they dedicated to the study of the English language per week (Table 1).

\begin{tabular}{|l|c|c|c|c|c|}
\hline & N & Minimum & Maximum & Mean & $\begin{array}{c}\text { Standard } \\
\text { deviation }\end{array}$ \\
\hline Years of study & 42 & 4 & 13 & 7.88 & 2.28 \\
\hline $\begin{array}{l}\text { Mean of the time dedicated } \\
\text { to English per week. }\end{array}$ & 42 & 0 & 5 & 0.94 & 1.47 \\
\hline
\end{tabular}

Table 1. Years of study of the English language and hours dedicated to the study of English per week.

This information is extremely useful when analysing the learning characteristics of our students as they potentially affect the three domains of individual differences outlined by Naiman et al. (1978) and cited by Skehan (1989): teaching, context and the learner.

Similarly, we thought that data on students' self-perception would also be useful, and so we decided to gather information on the language skills they considered the most difficult (Table 2) and the easiest (Table 3). As shown in these tables the easiest skill seemed to be 'reading' and the most difficult 'speaking'. This was done in order to partially adapt the contents of the course to the self-perceived needs of the students as a group.

\begin{tabular}{|l|c|c|}
\hline & Frequency & Percentage \\
\hline Listening & 17 & 40.5 \\
\hline Writing & 6 & 14.3 \\
\hline Speaking & 19 & 45.2 \\
\hline Total & 42 & 100.0 \\
\hline
\end{tabular}

Table 2. The most difficult skill according to sample.

\begin{tabular}{|l|c|c|}
\hline & Frequency & Percentage \\
\hline Listening & 4 & 9.5 \\
\hline Writing & 10 & 23.8 \\
\hline Reading & 25 & 59.5 \\
\hline Speaking & 3 & 7.1 \\
\hline Total & 42 & 100.0 \\
\hline
\end{tabular}

Table 3. The easiest skill according to sample.

Hembree's work (1988) and Krashen's opinions (Young, 1992) corroborate the presence of a meaningful relationship of self-esteem and self-perceived linguistic competence with affective variables such as foreign language anxiety. Brandl (1987) and Gynan (1989) state that learner beliefs can potentially determine learning dysfunctions. 
As mentioned above, we had also passed the students a test related to lexical and GE contents. The results obtained, listed in Table 4, were used for determining the GE levels of our students at the beginning of the semester. Students were classified in four groups: (1) Post-Beginner, (2) Low-Intermediate, (3) Intermediate and (4) Upper-Intermediate. Students were informed of the results and those in groups 1 and 2 were told that additional effort should be necessary in order to fully engage in the course activities.

\begin{tabular}{|l|c|c|c|c|}
\hline & Minimum & Maximum & Mean & $\begin{array}{c}\text { Standard } \\
\text { Deviation }\end{array}$ \\
\hline $\begin{array}{l}\text { Use of English } \\
\text { (Maximum mark 80) }\end{array}$ & 43.00 & 73.00 & 59.6829 & 8.3679 \\
\hline $\begin{array}{l}\text { Vocabulary } \\
\text { (Maximum mark 40) }\end{array}$ & 16.00 & 36.00 & 26.7561 & 4.8517 \\
\hline $\begin{array}{l}\text { Mark } \\
\text { Maximum mark 120) }\end{array}$ & 62.00 & 108.00 & 86.4390 & 12.5121 \\
\hline
\end{tabular}

Table 4. Results of the General English Placement Test.

As it has been previously reported, the contents of the course were programmed independently of both the teachers and the students. We could not change the syllabus into a totally ESAP-oriented one, and had we been able to, it probably would not have been very useful for those students pertaining to groups 1 and 2 . Also, according to the information given in Table 1, we had a very heterogeneous group. No one had studied for fewer than 4 years and some of them even had been studying the foreign language for 13 years. For these, a GE course could be dull and useless. In addition, the information given in Tables 3 and 4 showed that they felt more confident about their reading ability than about the rest of their linguistic skills. So, we decided to devote seventy five per cent of the classroom time to developing general communicative skills and the remaining twenty five per cent was dedicated to working on Psychology texts. This way, while we respected the preprogrammed contents, we provided students with a specialised range of vocabulary, reading and information-processing skills that could meet their future professional needs.

There is a great deal of literature reporting experiments carried out with students intending to get training in technical or scientific areas. We have found abundant research carried out on ESP (Jordan, 1997; Dudley-Evans and St John, 1998), but the field of Psychology has not probably been widely explored.

\section{Profiles, needs and problems of the students}

Following Kennedy and Bolitho (1991) we have outlined the profile, needs and problems of the students as follows:

Students in their Psychology final years at the University of Murcia. 
- Needs

All of them require reading skills in their academic field to gain access to English publications. Some require work in listening to/writing/presenting English essays in their specific fields at international conferences/meetings. They have some need for social English for travelling abroad and at conferences.

\section{- Problems}

As previously mentioned, the students had a variety of learning styles and abilities. According to the information given in Table 6 some require substantial assistance; others had a better knowledge of English and consequently they could be more interested in an ESAP course.

\section{- Design of the syllabus and methodology}

We do not consider ESP as an area of development separate from the rest of English Language Teaching. Our course had units devoted to both General English and English for Psychologists. By studying General English they are expected to write and speak 'according to the rules.' The ESAP units could help them to get used to the vocabulary of this particular area for them to be able to read journal articles in their speciality in such a way as to identify the most newsworthy information (Swales, 2000)

To achieve positive academic results, a communicative integrated methodology was developed mainly based on cognitive aspects directed to favouring comprehension and the production of academic texts in the field of Psychology.

The contents of the course were as follows:

\section{- Linguistic skills:}

Throughout the course the students practised the speaking skill with different activities such as giving opinions and drawing conclusions from a text. The students wrote several short texts related to psychology, emphasising the planning of ideas and coherent structure. The passive auditory skill was developed by listening to different recordings. The students were asked to take notes in order to infer the meaning of the unknown words from the context, and to find out the key words and the main ideas stated in the text. Finally, reading was practised through work on various types of texts in order to recognise connectors, to distinguish relevant information and to identify general concepts.

\section{- Thematic areas:}

Units devoted to themes closely related to Psychology were included in order to provide them with a wide range of vocabulary relevant to their future professional interests (Gilbert Maceda, 1991): Fear and anxiety; Psychiatric Psychology; Some questions used in an experiment; The mental illness model in psychiatric treatment; Animal mating behaviour; The language of emotion; Psychotherapy; Hyperactive children; Cocaine: Use or abuse?; Aspects of motion perception. 
- The communicative functions and the grammatical content of the course were those corresponding to an intermediate level. (See Reward Intermediate, Heinemann for References).

- Organisation of the course: 4 hours per week. The course was given by two Spanish teachers with the help of an assistant English teacher in the practical sessions, those devoted to developing oral fluency and listening skills.

\section{- Assessment}

As previously stated, the final mark of our course was based on a $75 \% / 25 \%$ ratio, the first figure corresponding to the GE component. Course assessment, according to University requirements, was carried out at the end of the semester through two different tests: one of them, a Use of English test, to evaluate students' proficiency in General English and the other to evaluate the ESAP component. Both, the GE and ESAP blocks received as much weight in the tests as time had been devoted to each part during the course (75\% and $25 \%$, respectively). The GE mark was calculated using a test which included multiple choice questions on the contents previously enumerated and which had been studied during the course. The ESAP mark was calculated using a test which considered the type of work performed during the course and which focussed on texts covering the ESAP contents listed before. The reading skill was measured through the ESAP test. As for the speaking, writing and listening skills, they were assessed through different activities throughout the course. The results obtained in these activities were considered to complete the final mark. In summary, three marks were obtained: GE, ESAP and the sum of both, FINAL.

\section{Results of the tests, analysis of the data and discussion}

The results ( $n=42$ ) of such assessment were the following:

\begin{tabular}{|l|c|c|c|c|}
\hline & Maximum & Minimum & Mean & $\begin{array}{c}\text { Standard } \\
\text { Deviation }\end{array}$ \\
\hline General English & 70.83 & 22.92 & 47.9660 & 11.8447 \\
\hline ESAP & 16.07 & 2.68 & 9.4631 & 3.4853 \\
\hline FINAL mark & 86.60 & 29.47 & 57.4812 & 13.8504 \\
\hline
\end{tabular}

Table 5. Results of the assessment carried out at the end of the semester.

As we were aware of the probable influence of motivation on the development of the course, we were very much interested in finding the possible relationships between students' motivation and their final results. The data we obtained are listed in tables 6 and 7 . 


\begin{tabular}{|l|c|c|c|c|}
\hline & Minimum & Maximum & Mean & $\begin{array}{c}\text { Standard } \\
\text { Deviation }\end{array}$ \\
\hline CCGlobal $^{1}$ & 62.00 & 108.00 & 91.3333 & 11.4644 \\
\hline General English Final & & & & \\
Mark & 25.42 & 70.83 & 50.1943 & 11.7675 \\
\hline ESAP Final mark & 4.76 & 16.07 & 10.2171 & 3.3053 \\
\hline Final & 34.05 & 86.60 & 60.4114 & 13.7861 \\
\hline
\end{tabular}

Table 6 . Students with motivation $=I$ like learning English.

\begin{tabular}{|l|c|c|c|c|}
\hline & Minimum & Maximum & Mean & $\begin{array}{c}\text { Standard } \\
\text { deviation }\end{array}$ \\
\hline CCGlobal & 62.00 & 102.00 & 81.30000 & 11.7029 \\
\hline General English Final & & & & \\
Mark & 22.92 & 69.79 & 45.7376 & 11.7773 \\
\hline ESAP Final mark & 2.68 & 15.77 & 8.7090 & 3.5754 \\
\hline Final & 29.47 & 85.86 & 54.5510 & 13.6078 \\
\hline
\end{tabular}

Table 7 . Students with motivation $=$ labour reasons.

As it can be seen, the students with integrative motivation got the highest marks both in GE and ESP, and obviously in the final mark. There are different researchers such as Arnold and Douglas (1999) who report correlations between integrative motivation and success in the L2. However, other authors describe that such correlations disappear when variables such as age are statistically controlled (Oyama, 1978; Purcell and Suter, 1980). This is not the case in our research since this experiment was carried out with adults whose age ranged between 21 and 28, as previously reported. Our results agree with Arnold and Douglas who indicate that, while instrumental motivation can also be beneficial, learning is most favourably influenced by integrative orientations.

Two tables (Tables 2 and 3) with data about the skills that the students manifested to be the easiest and the most difficult have been included in Procedures. According to these figures, $59.5 \%$ of the students stated that reading was the easiest skill, whereas $45.2 \%$ said that speaking was the most difficult, followed by listening (40.5\%) and writing (14.3\%). We were interested in the possible correlations, if any, between self-perception and the final results. They are listed in Tables $8,9,10$ and 11 .

\begin{tabular}{|l|c|c|c|c|c|}
\hline & $\mathrm{N}$ & Minimum & Maximum & Mean & $\begin{array}{c}\text { Standard } \\
\text { Deviation }\end{array}$ \\
\hline CC Global & 24 & 62.00 & 108.00 & 85.6250 & 13.2953 \\
\hline $\begin{array}{l}\text { General English } \\
\text { Final Mark }\end{array}$ & 25 & 22.92 & 70.83 & 48.1460 & 13.0493 \\
\hline ESP Final Mark & 25 & 2.68 & 15.77 & 9.1420 & 3.6256 \\
\hline FINAL Mark & 25 & 29.47 & 86.60 & 57.2876 & 15.5499 \\
\hline
\end{tabular}




\begin{tabular}{|l|l|l|l|l|l|}
\hline $\begin{array}{l}\text { Valid N (according to } \\
\text { the list) }\end{array}$ & 24 & & & & \\
\hline
\end{tabular}

Table 8. Descriptive data of those who said that reading was the easiest skill.

\begin{tabular}{|l|c|c|c|c|c|}
\hline & $\mathrm{N}$ & Minimum & Maximum & Mean & $\begin{array}{c}\text { Standard } \\
\text { Deviation }\end{array}$ \\
\hline CC Global & 17 & 62.00 & 108.00 & 86.5882 & 14.2568 \\
\hline $\begin{array}{l}\text { General English } \\
\text { Final Mark }\end{array}$ & 17 & 22.92 & 66.67 & 48.1353 & 13.6743 \\
\hline ESP Final Mark & 17 & 2.68 & 16.07 & 9.6565 & 3.8413 \\
\hline FINAL Mark & 17 & 29.47 & 82.74 & 57.9212 & 16.0684 \\
\hline $\begin{array}{l}\text { Valid N (according to } \\
\text { the list) }\end{array}$ & 17 & & & & \\
\hline
\end{tabular}

Table 9. Descriptive data of those who said that listening was the most difficult skill.

\begin{tabular}{|l|c|c|c|c|c|}
\hline & N & Minimum & Maximum & Mean & $\begin{array}{c}\text { Standard } \\
\text { Deviation }\end{array}$ \\
\hline CC Global & 6 & 75.00 & 103.00 & 93.9333 & 10.5530 \\
\hline $\begin{array}{l}\text { General English } \\
\text { Final Mark }\end{array}$ & 6 & 35.42 & 69.79 & 54.1667 & 11.8203 \\
\hline ESP Final Mark & 6 & 3.57 & 15.77 & 9.9700 & 4.0658 \\
\hline FINAL Mark & 6 & 45.24 & 85.86 & 64.1367 & 13.6224 \\
\hline $\begin{array}{l}\text { Valid N (according to } \\
\text { the list) }\end{array}$ & 6 & & & & \\
\hline
\end{tabular}

Table 10. Descriptive data of those who said that writing was the most difficult skill.

\begin{tabular}{|l|c|c|c|c|c|}
\hline & $\mathrm{N}$ & Minimum & Maximum & Mean & $\begin{array}{c}\text { Standard } \\
\text { Deviation }\end{array}$ \\
\hline CC Global & 18 & 62.00 & 106.00 & 83.8333 & 10.8533 \\
\hline $\begin{array}{l}\text { General English } \\
\text { Final Mark }\end{array}$ & 19 & 25.42 & 70.83 & 45.8563 & 9.8489 \\
\hline ESP Final Mark & 19 & 5.06 & 15.77 & 9.1300 & 3.1182 \\
\hline FINAL Mark & 19 & 34.05 & 86.60 & 54.9858 & 11.5923 \\
\hline $\begin{array}{l}\text { Valid N (according to } \\
\text { the list) }\end{array}$ & 18 & & & & \\
\hline
\end{tabular}

Table 11. Descriptive data of those who said that speaking was the most difficult skill.

The descriptive data of those who manifested that reading was the easiest skill are included in Table 10 and according to them the mean of the ESP final mark was 9.1420. This implies that, in this case, auto-perception does not match the final results as far as reading is concerned.

With respect to the rest of the skills, the best results both in the GE and ESAP final marks were of those for whom the most difficult skill was 'writing'. They were only 6 students, $14.3 \%$ of the people involved in the study. They were probably the best students at the beginning of the course. In our opinion, the students who manifest that writing is the 
most difficult skill have probably a dominion over the rest of the skills, even when they are not conscious of it.

The two remaining groups, those who said that 'listening' and 'speaking' were the most difficult skills, had right perceptions as has been shown through the corresponding data listed in Tables 11 and 13.

\section{Conclusions}

Considering the results of the placement and final tests, as well as the correlation between students' motivation and their final marks, we are tempted to postulate that, according to our initial assumption, those students with a better communicative competence at the beginning of the course obtained the best results in the final exam. A correlation between those students with intrinsic motivation and communicative competence and the highest final marks has also been found, which agrees with the research of Gardner and Lambert (1972), Gardner (1988), Jordan (1997) and Arnold (1999). As far as the reasons are concerned, we can advance several: the first one, students only dedicate 0.93 hours per week as a mean to studying English (Table 3), which is actually very scarce time to learn a foreign language.

We think that, maybe, one of the clues for understanding the academic output of this course should be found in the students' self-perception of their abilities. Put in another way, they did not succeed as regards self-confidence. When we passed them the initial battery of tests, $59.5 \%$ of the students manifested (Tables 2 and 3 ) that reading was the easiest skill and this, was one of the reasons for us to include some ESAP units. We did it in the belief that a good balance between TALO (Text as a Linguistic Object) and TAVI (Text as a Vehicle of Information) reading microskills (Johns and Davies, 1983) would favour the learning process. In a similar way, we felt that students could find themselves at ease within a non-threatening foreign language learning skill environment. Besides, in the final exam the ESAP assessment was carried out through the reading of some Psychology texts (the comprehension-reading skill was determinant to successfully pass this part).

There are also other facts which could explain the results obtained in this piece of research: one of them could be that, to our surprise, students are not probably as much interested in an ESAP course as in a GE one. Another possibility is that students enrolled this course only to complete some credits of their University curriculum, or they may think that English is not a subject as important as others specific to their degree and, as a consequence, they have devoted much more time to those than to English.

In our opinion, for this type of courses to have the chance of being successful, they should be redesigned as far as the number of students per class and the previous requirements are concerned. Dudley-Evans and St John (1998) state that dealing with large classes provides the teachers with some opportunities for innovation, such as running classes at alternative times, splitting classes or getting the authorities to increase resources. We have not even had the chance of applying such innovations. We have been working with $42-50$ students, which is too high a number for each student to fully benefit from the 
course. With reference to the students' previous academic requirements to enrol on the course, we think that the institution should include an initial requirement concerning the $\mathrm{L} 2$ level such as secondary school English learning background. Another possibility would be the development of two parallel and different courses to fulfil students' needs: one fully devoted to GE and the other focussed on ESAP. Similarly, a more flexible assessment framework or a modular approach would deserve further research and consideration.

However appealing these last proposals may be, we are well aware of the difficulties which changing curricula at the university level could raise. Therefore, we believe that feasible solutions should be explored that account for a more balanced, integrative and pragmatic approach to integrating GE and ESAP contents.

\section{Notes}

1. CCGlobal should be understood as Global Communicative Competence.

\section{Works cited}

Aesdibacher, U. (1986): Unterrichtsziel: Verstehen. Munich: Klett-Verlag.

Alcaraz, E. (2000): El Inglés profesional y académico. Madrid: Alianza Editorial, S.A.

Arnold, J. and Douglas Brown, H. (1999): A Map on the Terrain. In J. Arnold, Affect in Language Learning, Cambridge: CUP.

Brandl, K. (1987): Ecclecticism in Teaching Communicative Competences. Ph.D. Thesis. University of Texas, Austin.

Dudley-Evans, Tony and St John Maggie Jo (1998): Developments in English for Specific Purposes. A multi-disciplinary approach. Cambridge: CUP.

Gardner, R.C. (1988): "The Social-Educational Model of Second-Language Learning: Assuptions, Findings and Issues" Language Learning, 38: 101-126.

Gardner, R.C., Clement, R, Smythe, P.C. and C.L. Smythe (1979): The Attitude/Motivation Test Battery Revised Manual (Research Bulletin No. 15), Londres, Ontario.

Gardner, R.C. and W. Lambert (1959): "Motivational Variables in Second Language Acquisition" Canadian Journal of Psychology 13: 266-272. (1972): Attitudes and Motivation in Second Language Learning. Rowley, MA: Newbury House.

Gilbert Maceda, M.T. (1991): Inglés para Universitarios. Madrid: Universidad Nacional de Educación a Distancia.

Greenall, S. (1995): Heinemann Reward Student's Book. Intermediate. Oxford: Heinemann ELT. Gynan, S. (1989): Preferred Learning Practices of Selected Foreign Language Students. Presentation at the Annual Conference of Spanish Language Teachers Association. San Antonio, Texas.

Heinemann Reward Teacher Resource. (1998): Intermediate. Oxford: Heinemann ELT.

Hembree, R. (1988): "Correlates, Causes, Effects and Treatment of Test Anxiety". Review of Educational Research 58: 47-77.

Hutchinson, T. and Waters, A. (1987): English for Specific Purposes. A learning-centred approach. Cambridge: CUP. 
Johns, T. F and Davies, F. (1983): "Text as a vehicle for information: the class room use of written texts in teaching reading in a foreign language". Reading in a Foreign Language, I:1-19.

Jordan, R.R. (1997): English for Academic Purposes: A Guide and Resource Book for Teachers. Cambridge: CUP.

Kennedy, Ch. and Bolitho, R. (1991): English for Specific Purposes. London: Macmillan Press, Ltd.

Naiman, N. et al. (1978): "The Good Language Learner". Research in Education Series, 7. Ontario: Institute for Studies in Education.

Oyama, S. (1978): "The Sensitive Period of Comprehension and Speech". Working Papers of Bilingualism, 16: 1-18.

Purcell, E. and Suter, R. (1980): "Predictors of Pronunciation Accuracy: A Reexamination". Language Learning, 40: 271-287.

Richterich, R. and Chancerel, J.L. (1980): Identifying the Needs of Adults Learning a Foreign Language. Oxford: Pergamon Press.

Robinson, P.C. (1991): ESP Today: A Practitioner's Guide. Hemel Hempstead: Prentice Hall.

Skehan, P. (1989): Individual Differences in Second Language Learning. Londres: Edward Arnold.

Swales, J.M. (2000): English in academic and research settings. Cambridge: CUP.

Widdowson, H.G. (1998): "Communication and community: The pragmatics of ESP". ESP. 17.1: 3-14.

Young, D.J. (1992): "Language Anxiety from the Foreign Language Specialist's Perspective: Interviews with Krashen, Omaggio Hadley, Terrell and Rardin". Foreign Language Annals 25,2 . 